\title{
Serum Osteocalcin, Zinc Nutritive Status and Bone Turnover in Children and Adolescents with Type1 Diabetes Mellitus
}

\section{Abo-El-Asrar M1, Samar M Farid ${ }^{1 *}$, Mohamed O El Maraghy² and Ahmed K Mohamedeen}

${ }^{1}$ Department of Pediatrics, Ain Shams University, Cairo, Egypt

${ }^{2}$ Department Clinical Pathology, Ain Shams University, Cairo, Egypt

Keywords: Type 1 diabetes mellitus; HbA1c; Serum zinc; Serum osteocalcin

\section{Introduction}

It has been recognized that the alterations in mineral and bone metabolism were associated with DM and that the resulting bone loss is one of the chronic complications of diabetic patients [1]. Osteocalcin, is one of the osteoblast-specific proteins. It is the most abundant bone metabolic protein produced by osteoblast and thus reflects osteoblastic function [2]. Zinc has stimulatory effect on important hormones involved in bone growth such as growth hormone, serum IGF-IGFBP-3, alkaline phosphatase and osteocalcin [3].

This work aimed to study the effect of dietary zinc intake on bone turnover measured through serum Osteocalcin level in patients with $\mathrm{T} 1 \mathrm{DM}$, in addition to define different factors affecting it.

\section{Procedure}

The study included 60 children and adolescents with T1DM recruited from Diabetes Clinic, Ain-shams University. Controls consisted of 40 healthy children and adolescents matched in age, gender, BMI and pubertal staging to the study group. A written consent was taken from the parents of both patients and controls. Patients known to take medication that affect bone metabolism was excluded e.g. $(\mathrm{Ca}$, vitamin -D or steroids). All patients presented in the study had normal serum vitamin $\mathrm{D}$ level.

Demographic and disease related data were taken, including; age of onset and duration of diabetes, regimen, type and dose of insulin used, history of chronic bone-aches or previous bone fracture on minor trauma and the recorded full dietary intake for 3 days prior to the study [4] to determine the mean dietary zinc intake.

Physical examination including anthropometric measurements and pubertal staging [5] were recorded. Patients with tanner stage

\begin{tabular}{|l|l|l|l|l|}
\hline Variable & Patients $(\mathrm{n}=60)$ & Controls $(\mathrm{n}=40)$ & Test of sig. & $\mathrm{P}$ value \\
\hline $\begin{array}{l}\text { Daily dietary zinc intake } \\
(\mathrm{mg} / \mathrm{day})\end{array}$ & $6.24 \pm 2.6$ & $6.2 \pm 2.8$ & $\mathrm{t}=0.07$ & 0.94 \\
\hline Serum zinc $(\mu \mathrm{g} / \mathrm{dl})$ & $129.67 \pm 25.85$ & $131.3 \pm 20.88$ & $\mathrm{t}=-2.27$ & 0.78 \\
\hline $\begin{array}{l}\text { Serum Osteocalcin } \\
(\mathrm{ng} / \mathrm{ml})\end{array}$ & $24.52 \pm 10.84$ & $35.69 \pm 11.68$ & $\mathrm{t}=-4.89$ & $0.000^{*}$ \\
\hline
\end{tabular}

Table 1: Comparison between diabetic patients and control as regards daily dietary zinc intake, serum zinc and serum osteocalcin.

\begin{tabular}{|l|l|l|l|l|}
\hline Variable & $\begin{array}{l}\text { pre pubertal } \\
(\mathrm{n}=18)\end{array}$ & $\begin{array}{l}\text { Pubertal } \\
(\mathrm{n}=42)\end{array}$ & Test of sig. & P value \\
\hline Glycated $\mathrm{Hb} \%$ & $8.21 \pm 1.23$ & $9.05 \pm 1.87$ & 1.91 & 0.062 \\
\hline $\begin{array}{l}\text { Zinc daily dietary intake }(\mathrm{mg} / \\
\text { day })\end{array}$ & $5.59 \pm 2.74$ & $6.51 \pm 2.53$ & $\mathrm{t}=1.57$ & 0.215 \\
\hline Serum zinc $(\mu \mathrm{g} / \mathrm{dl})$ & $124.5 \pm 30.15$ & $132.31 \pm 23.79$ & $\mathrm{t}=1.15$ & 0.287 \\
\hline Serum osteocalcin $(\mathrm{ng} / \mathrm{ml})$ & $30.53 \pm 9.35$ & $21.94 \pm 10.49$ & $\mathrm{t}=8.97$ & $0.004^{* *}$ \\
\hline
\end{tabular}

Table 2: Comparison between prepubertal (tanner stage 1) and pubertal (tanner stage >1) diabetic patients as regards glycated $\mathrm{Hb} \%$, zinc daily dietary intake, serum zinc and serum osteocalcin.
1 are defined as prepubertal and those with tanner stage 2 or above are considered pubertal. Laboratory investigations included were; measurements of the mean fasting and postprandial blood glucose of the last month (at least 30 readings), the mean $\mathrm{HbAlc}$ of the last year measurements (4 reading), fasting serum osteocalcin measurement via ELISA and serum zinc assay by direct colorimetric method.

\section{Statistical analysis}

The data were processed on computer using SPSS (version 15). Chi-Square test was used to test the association variables for categorical data. Student's t-test was used to assess the difference between two independent samples. Correlation analysis was used to assess the association between two variables. Linear Regression analysis: was used to search for a panel (independent parameters) that can predict the target parameter (osteocalcin). P-values less than 0.05 were considered significant, while at 0.01 or 0.001 were considered highly significant

\section{Results}

This study was conducted on 60 children and adolescents with T1DM. They were 25 males and 35 females with a mean age of $12.23 \pm 4.26$ years. Patients and controls were well matching regarding demographic characteristics, anthropometric measurements and pubertal staging. Serum osteocalcin was significantly lower in diabetic patients compared to control group $(\mathrm{P}=0.00)$, While there was no significant difference regarding zinc dietary intake and serum zinc $(\mathrm{P}>0.05)$ (Table 1$)$. Serum osteocalcin was significantly higher in prepubertal patients compared to pubertal patients $(\mathrm{P}=0.004)$, while there was no statistical difference in serum zinc and dietary zinc intake as regards pubertal or prepubertal patients $(\mathrm{P}>0.05)$ (Table 2). Serum osteocalcin was lower in patients with $\mathrm{HbA1c} \geq 7.5$ compared to patients with $\mathrm{HbA1c}<7.5,(\mathrm{P}=0.014)$ Serum zinc and dietary zinc intake was significantly lower in patients with history of chronic bone aches $(\mathrm{P}<0.05)$, Serum osteocalcin was also lower in patients who had a history of chronic bone aches but of no statistical significant value ( $P>0.05$ ) (Table 3$)$. Daily dietary zinc intake was positively correlated with height, serum zinc and serum osteocalcin. While serum osteocalcin was significantly positively correlated with serum zinc, and it was significantly negatively correlated with age, age of onset, height, weight, BMI and HbA1c (Figure 1-4).

*Corresponding author: Samar Farid, Department of Pediatrics, Ain Shams University, Mohamed El makreef Street, Naser City, Cairo, Egypt, Tel: +202 26704485; E-mail: samarfarid 70@hotmail.com

Received March 16, 2011; Accepted May 13, 2011; Published May 16, 2011

Citation: Abo-El-Asrar M, Farid SM, Maraghy MOE, Mohamedeen AK (2011) Serum Osteocalcin, Zinc Nutritive Status and Bone Turnover in Children and Adolescents with Type1 Diabetes Mellitus. J Diabetes Metab 2:128. doi:10.4172/21556156.1000128

Copyright: (C) 2011 Abo-El-Asrar M, et al. This is an open-access article distributed under the terms of the Creative Commons Attribution License, which permits unrestricted use, distribution, and reproduction in any medium, provided the original author and source are credited. 


\begin{tabular}{|l|l|l|l|l|}
\hline Variable & $\begin{array}{l}\text { positive history of } \\
\text { bone aches }(\mathrm{n}=35)\end{array}$ & $\begin{array}{l}\text { negative history of } \\
\text { bone aches }(\mathrm{n}=25)\end{array}$ & Test of sig. & P value \\
\hline $\begin{array}{l}\text { Zinc daily dietary } \\
\text { intake }(\mathrm{mg} / \text { day) }\end{array}$ & $5.67 \pm 2.13$ & $7.03 \pm 3.02$ & $\mathrm{t}=2.04$ & $0.046^{*}$ \\
\hline $\begin{array}{l}\text { Serum zinc } \\
(\mu \mathrm{g} / \mathrm{dl})\end{array}$ & $123.71 \pm 20.06$ & $138.72 \pm 30.59$ & $\mathrm{t}=2.3$ & $0.025^{\star}$ \\
\hline $\begin{array}{l}\text { Serum osteocalcin } \\
(\mathrm{ng} / \mathrm{ml})\end{array}$ & $23.44 \pm 11.6$ & $26.02 \pm 9.7$ & $\mathrm{t}=0.91$ & 0.369 \\
\hline
\end{tabular}

Table 3: Comparison between diabetic patients with positive history of boneaches and those with negative history as regards daily dietary zinc intake, serum zinc and serum osteocalcin.

\begin{tabular}{|l|l|l|l|}
\hline Variable & R square & F & P value \\
\hline Tanner stage & 0.322 & 27.505 & 0.000 \\
\hline Zinc daily dietary intake & 0.462 & 24.510 & 0.000 \\
\hline HbA1c & 0.501 & 18.724 & 0.000 \\
\hline
\end{tabular}

Table 4: Linear multiregression analysis showing the most important predictors of serum osteocalcin level as a marker of bone turnover.

Regression analysis revealed that the most sensitive predictors for serum osteocalcin level as a marker of bone turnover were tanner staging, zinc dietary intake and $\mathrm{HbAlc}$ (Table 4).

\section{Discussion}

The changes in the bone mineral density (BMD) and bone turnover markers that occur in the two major clinical types of diabetes (type 1 and type 2) differ because they are associated with different pathogenetic mechanisms. While it is reduction of the BMD that most often occurs in T1DM, in type 2 diabetes various studies, diagnose either a normal, reduced or increased BMD [6].

In our study, patients and controls were well matched regarding age, gender, anthropometric measurements and pubertal staging in order to minimize the influence of age, gender, BMI and pubertal hormonal changes on altered bone metabolism. This study revealed that there was a significant lower serum osteocalcin in diabetic patients compared to controls. These result was in accordance with that reported by Thrailkill et al. [7] and Brandao et al. [8] On the other hand Alexopoulou et al. [9] found that there was no significant difference between patients with T1DM and controls regarding serum osteocalcin level. T1DM has been related to reduce BMD in childhood [10]. In addition, it has been recognized that insulin is essential for osteoblast function, as well as for chondrogenesis and collagen synthesis [11]. In patients with T1DM the impaired bone formation may result from absolute deficiency of insulin and insulin-like growth factor-1 (IGF1), which leads to lower values of peak bone mass [12].

No consensus has been reached as regards normal values for bone markers in healthy children. Bone marker levels increase during the first 3-4 years of life due to increased bone turnover and remains steady until the beginning of puberty, after which they appear to increase parallel to pubertal and height velocity. After 21 years of age, the bone markers return to pre-pubertal levels [13]. Suzuki et al. [1] reported a positive correlation between $\mathrm{PTH}$ and osteocalcin, it is speculated that the relative hypofunction of parathyroid gland causes the decreased activity of diabetic osteoblasts. Other study has demonstrated the evidence that the osteoblastic function was decreased whereas the osteoclastic function was conversely elevated in diabetic patients [14]. However, it has been still controversial if the osteoclastic function in diabetes is elevated or not.

This study revealed no difference between diabetic patients and controls regarding zinc dietary intake and serum zinc. Our results were in accordance with that reported by Cunningham et al. [15].
Meanwhile other studies observed that plasma zinc levels were lower in diabetic patients than controls [16,17]. Arreola et al. [16] showed a significant decrease in both bone mineral content and zinc, suggesting that zinc deficiency may be a contributory factor to bone loss in T1DM individuals with poor glycemic control. Zinc plays several roles in bone metabolism, work in cell cultures and animal models have shown stimulation of osteoblasts by zinc [18], while osteoclastic cell formation was inhibited [19]. In addition, the anabolic effect of IGF-I in osteoblasts is enhanced by zinc [20].

Hill et al. [21] showed that zinc stimulates osteoblasts in adults withT1DM. Zinc deficiency, however, impairs DNA synthesis and protein metabolism, negatively impacting bone formation [22]. A number of physiologic systems contribute to zinc homeostasis under different conditions. Changes in absorption of exogenous zinc and gastrointestinal secretion and excretion of endogenous zinc are the primary mechanisms for maintaining zinc homeostasis. Adjustments in renal excretion also occur with low or high intakes of zinc. Tissue and cellular redistribution of zinc may contribute further to the maintenance of zinc homeostasis $[23,24]$.

Serum osteocalcin was significantly higher in patients with $\mathrm{HbAlc}$ $\leq 7.5$ compared to patients with HbAlc $>7.5$. Previous studies suggested that metabolic control plays an important role in bone mineral density in patients with T1DM, so that; poorly glycemic controlled

$r=-0.405 p=0.001^{* *}$

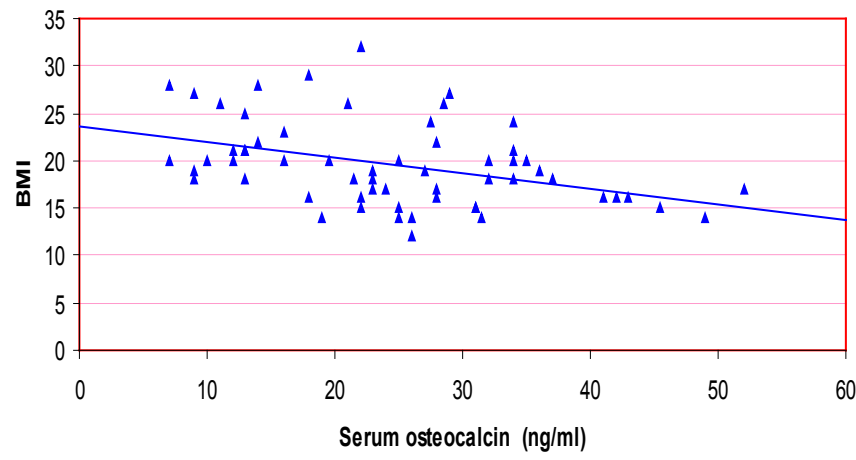

Figure1: Scatter diagram showing correlation between serum osteocalcin and BMI.

$r=-0.337 p=0.008^{* *}$

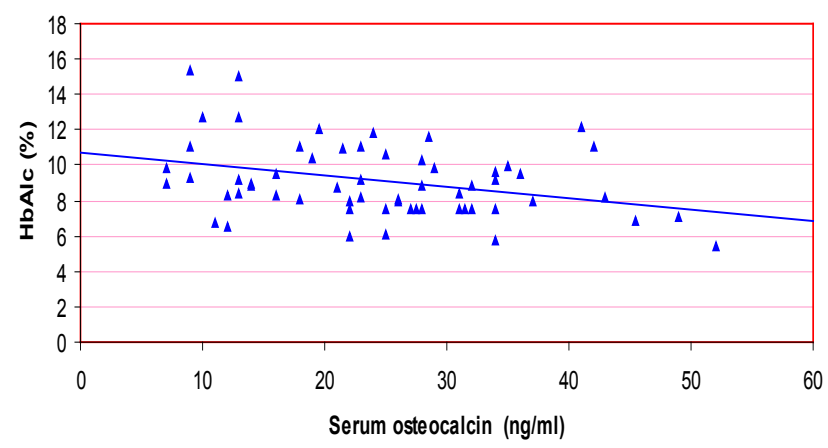

Figure 2: Scatter diagram showing correlation between serum osteocalcin and HbA1c. 


\section{$r=0.371 p=0.003^{* *}$}

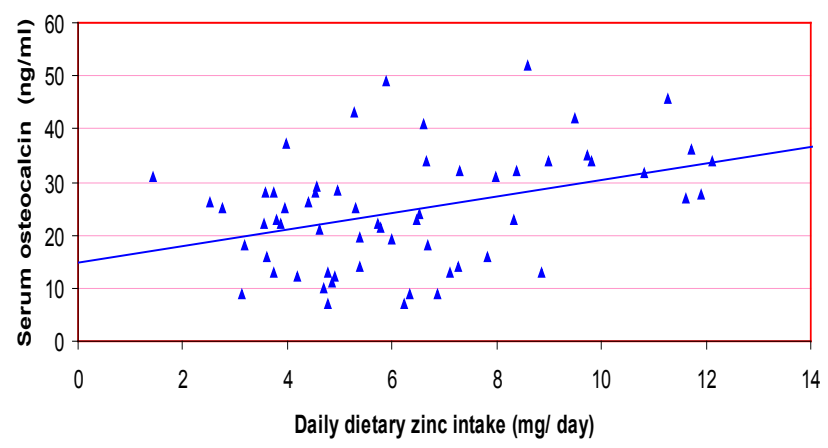

Figure 3: Scatter diagram showing correlation between daily dietary zinc intake and serum osteocalcin.

\section{$r=0.339 p=0.008^{\star \star}$}

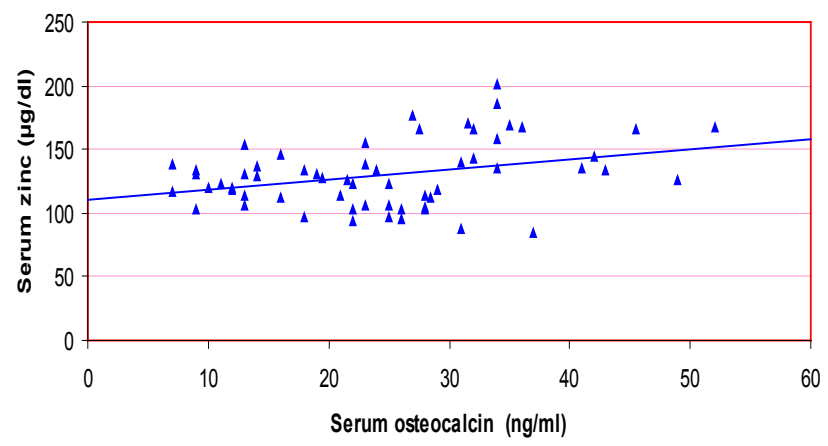

Figure 4: Scatter diagram showing correlation between serum osteocalcin and serum zinc.

patients had significantly lower osteocalcin level than good glycemic controlled patients $[8,10]$. The persistently poor metabolic control in adolescents with T1DM increases the risk of osteoporosis in adult life [25]. Furthermore, Campos et al. [26] reported that optimization of metabolic control could lead to a cessation of bone destruction after seven years duration of diabetes. Osteocalcin negatively correlated with fasting plasma glucose and $\mathrm{HbA1c}$ in both men and postmenopausal women [27]. On the other hand, Alexopoulou et al. [9] found that there was no influence of $\mathrm{HbAlc}$ on biomarkers of bone resorption and formation.

Our study revealed that diabetic patients with positive history of bone aches had significantly lower serum zinc and lower daily dietary zinc intake compared to those patients with negative history of boneaches. In addition, serum osteocalcin was lower in patients with history of bone aches compared to diabetic patients without history of boneaches but the results did not reach a statistically significant level. Inadequate intake of zinc has been reported as a risk factor for fractures in men [28]. Ozturk et al. [29] has suggested that zinc deficiency leads to an increase in free radical production. Oxidative stress has been shown to be an independent risk factor for osteoporosis [30].

This study revealed that serum osteocalcin negatively correlated with the duration of diabetes, but the results did not reach a statistical significance. Brandao et al. [8] found no correlation between the bone markers and the duration of diabetes. The impact of duration of diabetes on bone formation and markers of bone turnover has different explanations. Patients with recent onset T1DM may have impaired bone formation because of the absence of the anabolic effects of insulin, whereas in long-standing type 1 diabetes mellitus, vascular complications may account for low bone mass and increased fracture risk [31].

In our study, serum osteocalcin was negative correlated with age and BMI. These findings are in line with a previous study done by Cifuentes et al. [32] who showed that serum osteocalcin levels were higher in normal weight than in obese diabetic patients. They also reported a negative correlation between osteocalcin and body weight. In addition, Jee-Aee et al. [33] showed that serum osteocalcin level negatively correlated with BMI. Fares et al. [34] found that age and BMI negatively correlated with markers of bone formation.

Serum osteocalcin was significantly higher in prepubertal patients compared to pubertal patients. This is agreed with Brandao et al. [8] who found that osteocalcin is inversely related with pubertal development. Our study showed that dietary zinc intake and serum zinc is positively associated with osteocalcin as a marker of bone turnover in patients with T1DM. The effect of zinc supplementation on endogenous GH secretion, serum IGF-I and IGFBP-3 concentrations, bone formation markers, and linear growth of non-zinc-deficient children with idiopathic short stature showed direct stimulatory effect of zinc on serum alkaline phosphatase and osteocalcin [3]. Maser et al. [36] showed that zinc dietary intake positively correlated with serum osteocalcin. Logistic stepwise multiregression analysis revealed that the most sensitive predictors for serum osteocalcin level as a marker of bone turnover were tanner staging, zinc daily dietary intake and HbAlc respectively.

In conclusion, patients with type 1 diabetes found to have lower serum oseocalcin, which reflect a decreased activity of osteoblasts. Patients with poor glycemic control have lower serum osteocalcin. Normal serum Zinc and good Zinc dietary intake alone is not enough to improve osteoblastic function, but optimization of glucose metabolic profile in addition may help to improve osteoblasts activity and prevent bone complications. Longitudinal studies are required for following-up of bone turnover markers and bone mass in diabetic patients to assess the impact of different minerals intake.

\section{References}

1. Suzuki K, Sugimoto C, Takizawa M, Ishizuka S, Kikuyama M, et al. (2000) Correlation between bone mineral density and circulating bone metabolic markers in diabetic patients. Diabetes Res Clin Pract 48: 185-191.

2. Lian JB and Gundberg CM (1988) Osteocalcin: biochemical considerations and clinical applications. Clin Orthop 91: 226-267.

3. Imamoglu S, Bereket A, Turan S, Taga Y, Halkar G (2005) Effect of Zn Supplementation on growth hormone secretion, IGF-1, IGFBP-3, Somatomedin generation, alkaline phosphatase, Osteocalcin and growth in children with idiopathic short stature. J Pediatr Endocrinol Metab 18: 69-74.

4. Pehrsson PR, Haytowitz DB, Holden JM, Perry CR, Beckler DG (2000) USDA's National food and nutrient analysis program. Journal of food composition and analysis 13: $379-389$.

5. Tanner JM, Whitehouse RH, Takaishi M (1965) Standard from birth to maturity for height, weight, height velocity, and weight velocity: British children, 1965. II. Arch Dis Child 41: 613-635.

6. Botushanoy NP and Orbetzova MM (2009) Bone mineral density and fracture risk in patients with type 1 and type 2 diabetes mellitus. Folia Med (Plovdiv) 51: 12-17. 
Citation: Abo-El-Asrar M, Farid SM, Maraghy MOE, Mohamedeen AK (2011) Serum Osteocalcin, Zinc Nutritive Status and Bone Turnover in Children and Adolescents with Type1 Diabetes Mellitus. J Diabetes Metab 2:128. doi:10.4172/2155-6156.1000128

7. Thrailkill KM, Liu L, Wahl EC, Bunn RC, Perrien DS, et al. (2005a) Bone formation is impaired in a model of type 1 diabetes. Diabetes 54: 2875-2881.

8. Brandao F, Vicente E, Daltro C, Sacramento M, Moreira A, Adan L (2007) Bone metabolism is linked to disease duration and metabolic control in type 1 diabetes mellitus. Diabetes Res Clin Pract 78: 334-339.

9. Alexopoulou O, Jamart J, Devogelaer JP, Brichard S, de Nayer P, et al. (2006) Bone density and markers of bone remodeling in type 1 male diabetic patients Diabetes. Metab 32: 453-458.

10. Heap J, Murray MA, Miller SC, Jalili T, Moyer-Mileur LJ (2004) Alterations in bone characteristics associated with glycemic control in adolescents with type 1 diabetes mellitus. J Pediatr 144: 56-62.

11. Phornphutkul C, Wu KY, Gruppuso PA (2006) The role of insulin in chondrogenesis. Mol Cell Endocrinol 249: 107-115.

12. Milczarczyk A and Franek E (2008) Osteoporosis and bone fractures in patients with diabetes mellitus. Diabetologia Doświadczalna Kliniczna 8: 63-67.

13. Szulc P, Seeman E, Delmas PD (2000) Biochemical measurements of bone turnover in children and adolescents. Osteoporos Int 11: 281-294.

14. Suzuki K, Kurose T, Takizawa M, Maruyama M, Ushikawa K, et al. (2005) Osteoclastic function is accelerated in male patients with type 2 diabetes mellitus: the preventive role of osteoclastogenesis inhibitory factor/osteoprotegerin (OCIF/OPG) on the decrease of bone mineral density. Diabetes Research and Clinical Practice 68: 117-125

15. Cunningham JJ, Fu A, Mearkle PL, Brown RG (1994) Hyperzincuria in individuals with insulin-dependent diabetes mellitus: Concurrent zinc status and the effect of high-dose zinc supplementation. Metabolism 43: 1558-1562.

16. Arreola F, Paniagua R, Diaz-Bensussen S, Urquieta B, Lo'pez-Montaño E, et al. (1990) Bone mineral content, 25-hydroxycalciferol and zinc serum levels in insulin-dependent (type 1) diabetic patients. Arch Invest Med 21: 195-199.

17. Blostein-Fujii A, DiSilvestro RA, Frid D, Katz C, Malarkey W (1997) Shortterm zinc supplementation in women with non-insulin dependent diabetes mellitus: effects on plasma 5'-nucleotidase activities, insulin-like growth factor 1 concentrations, and lipoprotein oxidation rates in vitro. Am J Clin Nutr 66: 639-642.

18. Yamaguchi M, Hashizume M (1994) Effect of beta-alanyl-L-histidinato zinc on protein components in osteoblastic MC3T3-El cells: increase in osteocalcin insulin-like growth factor-I and transforming growth factor-beta. Mol Cell Biochem 136: 163-169.

19. Kishi S, Yamaguchi M (1994) Inhibitory effect of zinc compounds on osteoclastlike cell formation in mouse marrow cultures. Biochem Pharmacol 48: 12251230.

20. Matsui T, Yamaguchi M (1995) Zinc modulation of insulin-like growth factor's effect in osteoblastic MC3T3-E1 cells. Peptides 16: 1063-1068.

21. Hill T, Meunier N, Andriollo-Sanchez M, Ciarapica D, Hininger-Favier I, et al.
(2005) The relationship between the zinc nutritive status and biochemical markers of bone turnover in older European adults: ZENITH study. Eur J Clin Nutr 59: S73-S78.

22. llich JZ and Kerstetter JE (2000) Nutrition in bone health revisited: a story beyond calcium. J Am Coll Nutr; 19: 715-737.

23. Krebs NF (2000) Overview of zinc absorption and excretion in the human gastrointestinal tract. J Nutr 130: 1374S-1377S.

24. King JC and Cousins RJ (2006) Modern nutrition in health and disease. 10th ed. Baltimore: Lippincott Williams \& Wilkins, 271-285.

25. Valerio G, del Puente A, Esposito-del Puente A, Buono P, Mozzillo E, et al. (2002) The lumbar bone mineral density is affected by long-term poor metabolic control in adolescents with type 1 diabetes mellitus. Horm Res 58: 266-272.

26. Campos PMM, Lopez-Ibarra PJ, Escobar-Jimenez F, Serrano PMD, GarciaCervigon AG (2000) Intensive insulin therapy and bone mineral density in type 1 diabetes mellitus: a prospective study. Osteoporos Int 11: 455-459.

27. Kanazawa I, Yamaguchi T, Yamamoto M, Yamauchi M, Kurioka S, et al. (2009) Serum osteocalcin level is associated with glucose metabolism and atherosclerosis parameters in type 2 diabetes mellitus. J Clin Endocrinol Metab 94: $45-49$

28. Elmstahl S, Gullberg B, Janzon L, Johnell O, Elmstahl B (1998) Increased incidence of fractures in middle-aged and elderly men with low intakes of phosphorus and zinc. Osteoporos Int 8: 333-340

29. Ozturk A, Baltaci AK, Mogulkoc R, Oztekin E, Sivrikaya A, et al. (2003) Effects of zinc deficiency and supplementation on malondialdehyde and glutathion levels in blood and tissues of rats performing swimming exercise. Biol Trace Elem Res 94: 157-166

30. Sanchez-Rodríguez MA, Ruiz-Ramos M, Correa-Munoz E, Mendoza-Nunez VM (2007) Oxidative stress as a risk factor for osteoporosis in elderly Mexicans as characterized by antioxidant enzymes. BMC Musculoskelet Disord 8: 124 130

31. Hofbauer LC, Brueck CC, Singh SK, Dobnig H (2007) Review Osteoporosis in Patients with Diabetes Mellitus. J of bone and mineral research 22:1317-1328.

32. Cifuentes M, Johnson MA, Lewis RD (2003) Bone turnover and body weigh relationships differ in normal-weight compared with heavier postmenopausal women. Osteoporos Int 14: 116-122.

33. Jee-Aee I, Byung-Pal Y, Justin Y Jeon, Sang-Hwan K (2008) Relationship between osteocalcin and glucose metabolism in postmenopausal women. Clinica Chimica Acta 396: 66-69.

34. Fares JE, Choucair M, Nabulsi M, Salamoun M, Shahine $\mathrm{CH}$, et al. (2003) Effect of gender, puberty, and vitamin $\mathrm{D}$ status on biochemical markers of bone remodedeling. Bone 33: 242-247.

35. Maser ER, Stabley JN, Lenhard MJ, Owusu-Griffin P, Provost-Craig MA, et al. (2008) Zinc intake and biochemical markers of bone turnover in type diabetes. Diabetes Care 31: 2279-2280. 